\title{
Effectiveness of prison-based opioid substitution treatment: a systematic review
}

\begin{abstract}
Opioid substitution treatment (OST) is the most effective treatment for opioid dependence and plays critical role in $\mathrm{HIV} /$ Hepatitis $\mathrm{C}(\mathrm{HCV})$ prevention. Despite its proven effectiveness, OST is still significantly less available in prisons than in community setting. The aim of this systematic review is to review and evaluate evidence of the effectiveness of prison-based OST with regard to both in-prison and post-release outcomes. Systematic review was conducted of experimental and observational studies that reported effects of prison-based OST on heroin and crack use, injecting drug use, drug paraphernalia sharing, $\mathrm{HIV} / \mathrm{HCV}$ seroconversion, treatment retention, criminal activity, arrests, re-incarceration and mortality. PsycINFO, Medline and Science Direct databases were searched for relevant studies, published between 2003 and 2017. In total, 647 references were screened, with 19 studies selected and included in the review. Eleven observational and eight experimental studies were identified. Prison-based OST was shown to be significantly correlated with improved treatment uptake and retention and reduction of heroin use, injecting drug use, drug paraphernalia sharing and HIV/HCV seroconversion. Partial evidence emerged for its effectiveness in reduction of cocaine use, criminal activity and mortality. There was weak evidence for its impact on re-incarceration and no evidence for its reduction of arrests. Prison-based OST was shown to be effective in improvement of treatment uptake and retention and reduction of illicit drug use, injecting behaviour, drug paraphernalia sharing, HIV/HCV seroconversion, criminal activity and mortality. Prison-based OST is an opportunity to engage in drug treatment one of the most high-risk and hard-to-reach groups. Whilst further research is needed to explore its long-term outcomes, existing studies provide evidence for its effectiveness and strong argument for its wider implementation.
\end{abstract}

Keywords: opioid, hepatitis $\mathrm{C}$, heroin, addiction, prison setting
Volume 5 Issue 4 - 2018

\author{
Lana Durjava \\ Designation Independent Researcher, UK
}

Correspondence: Lana Durjava, Designation Independent Researcher, University N/A, 45c Goring Road, London, NI I2BT, UK, Tel 07544904I92, Email lana@lanadurjava.co.uk

Received: July 0I, 2018 | Published: July II, 2018
Abbreviations: OST, opioid substitution treatment; UNODC, united nations office on drugs and crime; HIV, human immunodeficiency virus; $\mathrm{HCV}$, hepatitis $\mathrm{C}$ virus; $\mathrm{HBV}$, hepatitis $\mathrm{B}$ virus; WHO, world health organisation

\section{Introduction}

Heroin addiction is a public health problem with significantly detrimental social and health consequences, and it disproportionally affects people who are incarcerated. ${ }^{1}$ Prevalence of heroin use in prisons in England and Wales is high, with 27\% prisoners reporting using the drug whilst in prison. ${ }^{2}$ Comparing the phenomenon of heroin use with use of other drugs, Strang et al., ${ }^{3}$ have shown that persistence of drug taking during incarceration is of higher occurrence among heroin users than among users of cocaine and amphetamine, whereas Boys et al., ${ }^{4}$ demonstrated that prisons present a high-risk environment not just for continuation but also for initiation of heroin use.

Heroin use carries multiple health, legal and social implications such as increased risk of blood borne viruses infections, injecting related complications, poor physical and mental health, criminal activity and impaired social functioning. ${ }^{5-8}$ Heroin use in prison setting carries additional challenges, with numerous studies showing that individuals who frequently use heroin during incarceration report engaging in riskier practices of heroin use in prison than in the community, ${ }_{5}^{5}$ with one of the factors contributing towards that being limited availability of harm reduction services in prisons. ${ }^{9-12}$ Heroin use in prison significantly increases the risks of HIV, Hepatitis $\mathrm{C}(\mathrm{HCV})$ and Hepatitis B (HBV) infection, ${ }^{13-16}$ overdose death upon release, ${ }^{17-19}$ criminal activity, ${ }^{20,21}$ and re-incarceration. ${ }^{22}$ Effective prison-based drug treatment for heroin dependence is therefore of vital importance for reduction of negative impact of dependent heroin use on both individual's health and social functioning, as well as on safety and welfare of the communities. ${ }^{21}$

Indeed, opioid substitution treatment (OST) has been shown to be the most effective treatment for chronic heroin dependence in both community, ${ }^{23-25}$ and prison setting. ${ }^{26-28}$ OST is treatment of heroin dependence with opioid agonists (methadone) or opioid partial agonists (buprenorphine and buprenorphine-naloxone) which can be offered as a short-term detoxification or long-term maintenance treatment. Research has shown that OST is substantially more effective when offered on a long-term basis. ${ }^{29,30}$ When administered at therapeutic doses (methadone $>60 \mathrm{ml}$, buprenorphine and buprenorphinenaloxone $>8 \mathrm{mg}$ ), OST has been shown to significantly reduce heroin use, HIV/HCV seroconversion, injecting drug use, overdose deaths and engagement in criminal activities. ${ }^{31-33}$ Additionally, it notably improves treatment retention, general health, employment stability, social functioning and overall quality of life. ${ }^{34,35}$ Due to their proven effectiveness, World Health Organisation, ${ }^{36}$ includes methadone and buprenorphine on the list of essential medicines and recommends them to be available to people by all health systems and governments. WHO also provides clear directives that provision of essential medicines and healthcare services should be of the same standard in prisons and community. ${ }^{36,37}$

Despite both WHO, ${ }^{36}$ and United Nations Office on Drugs and Crime, ${ }^{38}$ recommending OST in prisons as primary treatment for heroin dependence and essential intervention for HIV prevention, 
implementation of prison-based OST was significantly delayed in comparison with community-based OST. Research has demonstrated that in the past 30 years, the average time-lag between the introduction of community and prison-based OST has been between seven to eight years. ${ }^{39}$ Availability of prison-based OST in European countries has notably improved in the last decade, with all countries apart from Iceland, Monaco, Andora and Cyprus offering OST in at least some of their prisons. However, OST is generally still significantly less available in prison than in community setting. Numerous studies have found differences in provision of OST with accessibility in prisons restricted due to time-limited prescribing, longer waiting times and regional and institutional variability in quality of services. Some countries also do not allow in-prison initiation of OST and consequently provide OST only to prisoners who were receiving OST prior to incarceration. ${ }^{40,41}$ Additionally, despite their proven effectiveness only a small amount of countries currently provide needle exchange programmes in prisons. ${ }^{42}$ This is of great concern due to prevalence of high risk drug using behaviour in prisons with, depending on the country, $2 \%$ to $31 \%$ of prisoners in European prisons reporting having experience of injecting drugs during incarceration. ${ }^{41,43}$

Prison population has substantially higher rates of heroin dependence than general population, ${ }^{44}$ and although many heroindependent prisoners stop using heroin during incarceration, ${ }^{10}$ those who continue using more regularly share drug paraphernalia and are at substantially higher risk of $\mathrm{HIV} / \mathrm{HCV}$ seroconversion than heroin users in the community. ${ }^{45-47}$ Additionally, heroin-dependent prisoners are at higher risk of relapse and overdose upon release from prison, and often do not engage in community-based drug treatment. ${ }^{11,48,49}$

This systematic review aims to provide a comprehensive review about effectiveness of prison-based OST with regard to both in-prison and post-release outcomes. It is complemented by other systematic reviews about effectiveness of OST in community, ${ }^{24,50}$ and prison setting. ${ }^{51}$ The research question it aims to answer is: what is the effectiveness of OST for opioid-dependent prisoners with regard to heroin and crack use, injecting drug use, drug paraphernalia sharing, $\mathrm{HIV} / \mathrm{HCV}$ seroconversion, treatment uptake and retention, criminal activity, arrests, re-incarceration and mortality upon release from prison?

\section{Method}

The searches were conducted on PsycInfo, Medline and Science Direct databases. Inclusion criteria were publications between 2003 and 2017, in order to avoid too much overlapping with the literature review about OST in prison, conducted by Stallwitz \& Stover. ${ }^{51}$ Further inclusion criteria were relevance to the research question, methodological quality, English language and publications in peer- reviewed journals. Only studies that reported in-prison or post-release outcomes of prison-based OST for opioid-dependent prisoners were included.

The PsycINFO, Medline and Science Direct databases were searched using a combination of subject headings: (prison OR jail) AND (methadone OR opiate substitution treatment OR buprenorphine OR buprenorphine-naloxone). The PsyINFO database search yielded 164 articles, the Medline database search yielded 201 articles and the Science Direct database search yielded 282 articles. In total, this produced 647 articles which were screened, based on the abstracts. Articles were excluded from review if they did not report in-prison or post-release outcomes of prison-based OST for one or more variables: heroin use, cocaine use, injecting drug use, drug paraphernalia sharing, HIV/HCV incidence and seroconversion, treatment uptake and retention, criminal activity, arrests, re-incarceration and mortality. This screening process, followed by removal of duplicates, produced 19 articles which were read in full and analysed. The results of search strategy are shown in Figure 1.

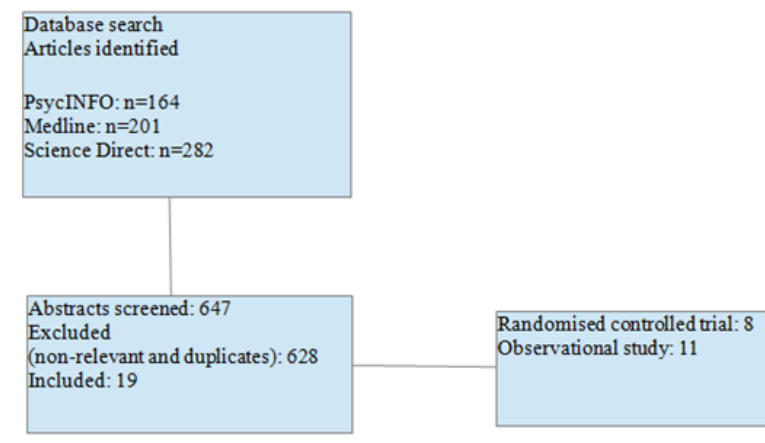

Figure I Search strategy.

\section{Results}

Studies are summarised in Table 1. Eleven studies were observational studies and eight were randomised controlled trials. Studies were conducted in USA (eight), Australia (seven), Puerto Rico (two), Scotland (one) and France (one). Interventions included maintenance on methadone (ten), buprenorphine (one), buprenorphine-naloxone (one) and methadone and buprenorphine (seven). Population of all studies were opioid-dependent prisoners, who were in most studies followed post-release for various lengths of time. Outcomes were measured in prison in four studies, post-release in thirteen studies and both pre- and post-release in two studies. Ten studies had male participants and nine studies had both male and female participants. None of the studies had solely female participants.

Table I Study Characteristics

\begin{tabular}{|c|c|c|c|c|c|c|c|c|}
\hline Author, date & Location & Intervention & Study design & Population & Sample $n$ & Outcomes & Specific outcomes & Follow-up \\
\hline Bird et al..$^{58}$ & Scotland & $\begin{array}{l}\text { Methadone and } \\
\text { buprenorphine }\end{array}$ & $\begin{array}{l}\text { Observational } \\
\text { retrospective study }\end{array}$ & $\begin{array}{l}\text { Heroin-dependent } \\
\text { prisoners }\end{array}$ & $\begin{array}{l}2770 \text { (male and } \\
\text { female) }\end{array}$ & Post-release & Mortality & $2-12$ weeks \\
\hline $\begin{array}{l}\text { Degenhardt } \\
\text { et al. }{ }^{59}\end{array}$ & Australia & $\begin{array}{l}\text { Methadone and } \\
\text { buprenorphine }\end{array}$ & $\begin{array}{l}\text { Observational } \\
\text { retrospective study }\end{array}$ & $\begin{array}{l}\text { Opioid-dependent } \\
\text { pre-release }\end{array}$ & $\begin{array}{l}16453 \text { (male } \\
\text { and female) }\end{array}$ & Post-release & Treatment retention & Not applicable \\
\hline \multirow[t]{2}{*}{ Dolan et al. ${ }^{55}$} & Australia & Methadone & Randomised & $\begin{array}{l}\text { prisoners } \\
\text { Heroin-dependent } \\
\text { prisoners }\end{array}$ & 382 males & In prison & Heroin use (hair test) & 4 months \\
\hline & & & controlled & & & & Heroin use (self-report) & \\
\hline
\end{tabular}


Table Continued

\begin{tabular}{|c|c|c|c|c|c|c|c|c|}
\hline Author, date & Location & Intervention & Study design & Population & Sample $n$ & Outcomes & Specific outcomes & Follow-up \\
\hline & & & trial & & & & $\begin{array}{l}\text { Injecting drug use } \\
\text { Drug paraphernalia sharing } \\
\text { HCV seroconversion }\end{array}$ & \\
\hline \multirow[t]{2}{*}{ Dolan et al..$^{60}$} & Australia & Methadone & $\begin{array}{l}\text { Observational } \\
\text { retrospective study }\end{array}$ & $\begin{array}{l}\text { Heroin-dependent } \\
\text { prisoners }\end{array}$ & 382 males & Post-release & Re-incarceration & 4 years \\
\hline & & & & & & & $\begin{array}{l}\text { HIV/HCV seroconversion } \\
\text { Mortality }\end{array}$ & \\
\hline \multirow[t]{4}{*}{ Garcia et al. ${ }^{61}$} & Puerto Rico & $\begin{array}{l}\text { Buprenorphine- } \\
\text { naloxone }\end{array}$ & $\begin{array}{l}\text { Observational } \\
\text { prospective study }\end{array}$ & $\begin{array}{l}\text { Opioid-dependent } \\
\text { pre-release }\end{array}$ & 45 males & Post-release & Morphine urinalysis & I month \\
\hline & & & & prisoners & & & Heroin use (Self-report) & \\
\hline & & & & & & & Cocaine use (Self-report) & \\
\hline & & & & & & & Criminal activities & \\
\hline Gisev et al. ${ }^{62}$ & Australia & $\begin{array}{l}\text { Methadone and } \\
\text { buprenorphine }\end{array}$ & $\begin{array}{l}\text { Observationalretro- } \\
\text { spective study }\end{array}$ & $\begin{array}{l}\text { Opioid-dependent } \\
\text { pre-release }\end{array}$ & $\begin{array}{l}16073 \text { (male } \\
\text { and female) }\end{array}$ & Post-release & Mortality & 6 months \\
\hline & & & & prisoners on OST & & & & \\
\hline \multirow[t]{7}{*}{ Gordon et al..$^{6}$} & USA & Methadone & Randomised & $\begin{array}{l}\text { Heroin-dependent } \\
\text { pre-release }\end{array}$ & 201 males & Post-release & Treatment retention & 6 months \\
\hline & & & controlled & prisoners & & & Opioid urinalysis & \\
\hline & & & trial & & & & Heroin use (self-report) & \\
\hline & & & & & & & Cocaine urinalysis & \\
\hline & & & & & & & Cocaine use (Self-report) & \\
\hline & & & & & & & Criminal activities & \\
\hline & & & & & & & Re-incarceration & \\
\hline \multirow[t]{3}{*}{ Gordon et al. ${ }^{56}$} & USA & Buprenorphine & Randomised & $\begin{array}{l}\text { Heroin-dependent } \\
\text { pre-release }\end{array}$ & $\begin{array}{l}2 I I \text { (male and } \\
\text { female) }\end{array}$ & $\begin{array}{l}\text { Pre- and } \\
\text { post-release }\end{array}$ & Entered prison treatment & 10 days \\
\hline & & & controlled & prisoners & & & Completed prison treatment & \\
\hline & & & trial & & & & Entered community treatment & \\
\hline Heimer et al. ${ }^{52}$ & Puerto Rico & Methadone & $\begin{array}{l}\text { Observationalretro- } \\
\text { spective study }\end{array}$ & $\begin{array}{l}\text { Opiate-using long- } \\
\text { term prisoners }\end{array}$ & 60 males & In prison & $\begin{array}{l}\text { Heroin use (self-report) } \\
\text { Morphine urinalysis } \\
\text { Methadone urinalysis }\end{array}$ & $\begin{array}{l}\text { I2 days-1I } \\
\text { months }\end{array}$ \\
\hline \multirow[t]{6}{*}{ Kinlock et al. ${ }^{66}$} & USA & Methadone & Randomised & $\begin{array}{l}\text { Heroin-dependent } \\
\text { pre-release }\end{array}$ & 211 males & Post-release & Treatment entry & I month \\
\hline & & & controlled & prisoners & & & Opioid urinalysis & \\
\hline & & & trial & & & & Heroin use (self-report) & \\
\hline & & & & & & & Cocaine urinalysis & \\
\hline & & & & & & & Cocaine use (Self-report) & \\
\hline & & & & & & & Mortality & \\
\hline \multirow[t]{7}{*}{ Kinlock et al. ${ }^{67}$} & USA & Methadone & Randomised & $\begin{array}{l}\text { Heroin-dependent } \\
\text { pre-release }\end{array}$ & 204 males & Post-release & $\begin{array}{l}\text { Community treatment } \\
\text { duration }\end{array}$ & 12 months \\
\hline & & & controlled & prisoners & & & Opioid urinalysis & \\
\hline & & & trial & & & & Heroin use (self-report) & \\
\hline & & & & & & & Cocaine urinalysis & \\
\hline & & & & & & & Cocaine use (Self-report) & \\
\hline & & & & & & & Criminal activities & \\
\hline & & & & & & & Arrests & \\
\hline \multirow[t]{2}{*}{ Kinner et al. ${ }^{53}$} & Australia & $\begin{array}{l}\text { Methadone and } \\
\text { buprenorphine }\end{array}$ & $\begin{array}{l}\text { Observationalretro- } \\
\text { spective study }\end{array}$ & $\begin{array}{l}\text { Opioid-dependent } \\
\text { prisoners }\end{array}$ & $\begin{array}{l}2453 \text { (male and } \\
\text { female) }\end{array}$ & In prison & Lifetime injecting drug use & Not applicable \\
\hline & & & & & & & In-prison injecting drug use & \\
\hline Larney et al..$^{63}$ & Australia & $\begin{array}{l}\text { Methadone and } \\
\text { buprenorphine }\end{array}$ & $\begin{array}{l}\text { Observationalretro- } \\
\text { spective study }\end{array}$ & $\begin{array}{l}\text { Heroin-dependent } \\
\text { pre-release }\end{array}$ & 375 males & Post-release & Treatment retention & 3 years \\
\hline
\end{tabular}




\begin{tabular}{|c|c|c|c|c|c|c|c|c|}
\hline Author, date & Location & Intervention & Study design & Population & Sample $n$ & Outcomes & Specific outcomes & Follow-up \\
\hline & & & & prisoners & & & Re-incarceration & \\
\hline \multirow[t]{5}{*}{ Magura et al. ${ }^{57}$} & USA & $\begin{array}{l}\text { Buprenorphine vs } \\
\text { methadone }\end{array}$ & Randomised & $\begin{array}{l}\text { Opioid-dependent } \\
\text { short-term } \\
\text { prisoners }\end{array}$ & 133 males & $\begin{array}{l}\text { Pre- and } \\
\text { post-release }\end{array}$ & $\begin{array}{l}\text { Pre-release: completed } \\
\text { treatment in prison }\end{array}$ & 3 months \\
\hline & & & controlled & & & & Intent to continue treatment & \\
\hline & & & trial & & & & Post-release: treatment entry & \\
\hline & & & & & & & Heroin use (self-report) & \\
\hline & & & & & & & Re-incarceration Arrests & \\
\hline \multirow[t]{2}{*}{ Marzo et al..$^{64}$} & France & $\begin{array}{l}\text { Buprenorphine or } \\
\text { methadone }\end{array}$ & $\begin{array}{l}\text { Observationalretro- } \\
\text { spective study }\end{array}$ & Opioid-dependent & $\begin{array}{l}507 \text { (male and } \\
\text { female) }\end{array}$ & Post-release & Re-incarceration & $\begin{array}{l}3 \text { years (24-39 } \\
\text { months) }\end{array}$ \\
\hline & & & & prisoners & & & Mortality & \\
\hline $\begin{array}{l}\text { McMillan et } \\
\text { al. }{ }^{65}\end{array}$ & USA & Methadone & $\begin{array}{l}\text { Observationalretro- } \\
\text { spective study }\end{array}$ & $\begin{array}{l}\text { Opioid-dependent } \\
\text { prisoners in OST } \\
\text { at the time of } \\
\text { arrest }\end{array}$ & $\begin{array}{l}589 \text { (male and } \\
\text { female) }\end{array}$ & Post-release & Re-incarceration & 12 months \\
\hline \multirow[t]{6}{*}{ Rich et al. ${ }^{68}$} & USA & Methadone & Randomised & Opioid-dependent & $\begin{array}{l}283 \text { (male and } \\
\text { female) }\end{array}$ & Post-release & Treatment retention & I month \\
\hline & & & controlled & prisoners & & & Opioid use (self-report) & \\
\hline & & & trial & & & & Other drug use (self-report) & \\
\hline & & & & & & & Injecting drug use & \\
\hline & & & & & & & Non-fatal overdoses & \\
\hline & & & & & & & Mortality & \\
\hline Teutsch et al. ${ }^{54}$ & Australia & Methadone & $\begin{array}{l}\text { Observationalretro- } \\
\text { spective study }\end{array}$ & $\begin{array}{l}\text { Drug-injecting } \\
\text { prisoners with } \\
\text { negative } \mathrm{HCV} \text { test } \\
\text { in past } 12 \text { months }\end{array}$ & $\begin{array}{l}488 \text { (male and } \\
\text { female) }\end{array}$ & In prison & $\mathrm{HCV}$ incidence & 12 months \\
\hline \multirow[t]{3}{*}{ Wilson et al. ${ }^{69}$} & USA & Methadone & Randomised & $\begin{array}{l}\text { Heroin-dependent } \\
\text { pre-release }\end{array}$ & 211 males & Post-release & Drug paraphernalia sharing & $\begin{array}{l}1,3,6 \text { and } 12 \\
\text { months }\end{array}$ \\
\hline & & & controlled & prisoners & & & Sex risk behaviour & \\
\hline & & & trial & & & & Injecting drug use & \\
\hline
\end{tabular}

\section{Effectiveness of prison-based OST}

Effectiveness of prison-based OST was assessed with regard to in-prison and post-release outcomes.

\section{Prison-based OST and in-prison outcomes}

Six studies reported in-prison outcomes for prison-based OST. Three were observational studies, ${ }^{52-54}$ and three were randomised controlled trials. ${ }^{55-57}$

\section{Heroin use}

Two studies with follow up periods between twelve days and eleven months examined heroin use during incarceration. Both of them reported significant reductions in heroin use in participants who were receiving prison-based OST. In Heimer et al., ${ }^{52}$ observational study, the percentage of OST-receiving participants who were using heroin was reduced for $94 \%$, according to self-report and $95 \%$, according to urinalysis Only $5.6 \%$ of OST-receiving participants reported heroin use. In contrast, a rate of heroin use amongst participants who were not receiving OST was significantly higher $(\mathrm{p}<.05)$, with $35 \%$ of them reporting heroin use in the previous month.

Dolan et al., ${ }^{55}$ experimental study compared heroin use between OST-receiving prisoners and control group. Percentage of OST- receiving prisoners who injected heroin was decreased from $60 \%$ to $32 \%$, whereas percentage of control subjects who injected heroin increased from $68 \%$ to $74 \%$. Mean number of heroin injections that participants reported per month which were reported on a monthly basis was also significantly lower $(\mathrm{p}<.001)$ among OST-receiving participants than control subjects.

\section{Injecting drug use}

Two studies reported on in-prison injecting drug use and produced mixed results. In Dolan et al., ${ }^{55}$ experimental study with follow up in four months, percentage of OST-receiving prisoners who injected heroin or other drugs was decreased from $64 \%$ to $34 \%$, whereas percentage of control subjects who injected drugs increased from $70 \%$ to $76 \%$. Mean number of heroin injections that participants reported per month which were reported on a monthly basis was also significantly lower $(\mathrm{p}<.001)$ among OST-receiving participants than control subjects. On the other hand, Kinner et al., ${ }^{53}$ observational study found no significant difference of in-prison injecting drug use among prisoners who were receiving OST and those who were not.

\section{Drug paraphernalia sharing}

One experimental study, ${ }^{55}$ investigated drug paraphernalia sharing during incarceration, comparing OST-receiving prisoners and 
control subjects. The month prior to beginning of treatment, $41 \%$ of participants who later received OST and $36 \%$ of control subjects reported sharing drug paraphernalia. However, OST-receiving prisoners were significantly less likely $(\mathrm{p}<.001)$ to report sharing drug paraphernalia at follow up (reduction from $41 \%$ to $15 \%$ ) than control subjects (increase from $36 \%$ to $44 \%$ ).

\section{HIV/HCV incidence and seroconversion}

Two studies examined HIV/HCV incidence and seroconversion. In Dolan et al., ${ }^{55}$ experimental study, HIV prevalence was zero both at baseline and follow up for all participants. Baseline HCV antibody seroprevalence was $76 \%$ for OST-receiving prisoners and $72 \%$ for control subjects. Whilst seroincidence was lower for OSTreceiving prisoners than for control subjects, the difference was not significant ( $\mathrm{p}>.05)$. On the other hand, Teutsch et al., ${ }^{54}$ observational study found that HCV incidence was significantly higher $(\mathrm{p}<.001)$ in OST-receiving prisoners than control subjects ( $38 \%$ versus $16 \%$ ). However, as the study did not report on HCV seroconversion it is unclear whether OST-receiving prisoners acquired HCV prior to or during OST treatment.

\section{Treatment completion}

Two experimental studies investigated in-prison treatment completion for OST-receiving prisoners. Gordon et al., ${ }^{56}$ compared treatment completion rates between prisoners who were receiving buprenorphine and prisoners who were receiving only counselling, and found no significant differences ( $p>.05)$. Magura et al., ${ }^{57}$ conducted randomised controlled trial, comparing treatment completion between prisoners who were receiving methadone and prisoners who were receiving buprenorphine. No significant difference was found ( $p>05)$ and completion rates for both groups were similarly high $(82 \%$ for buprenorphine treated prisoners and $75 \%$ for methadone treated prisoners).

\section{Prison-based OST and post-release outcomes}

Fifteen studies reported in-prison outcomes for prison-based OST. Eight were observational studies, ${ }^{58-65}$ and seven were randomised

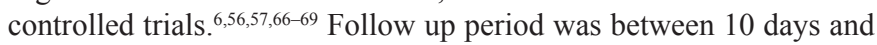
4 years.

\section{Heroin use}

Six studies with follow up periods between one and twelve months reported on post-release heroin use. Five studies. ${ }^{6,61,66-68}$ found significant reduction $(\mathrm{p}<.05)$ of heroin use upon release among former prisoners who were receiving prison-based OST in comparison with control group. In four studies, ${ }^{6,61,66-68}$ OST treatment was methadone and in one study buprenorphine-naloxone. ${ }^{61}$ Magura et al. ${ }^{57}$ study compared participants in OST treatment with methadone and buprenorphine and found no significant differences in post-release heroin use among the two groups.

\section{Cocaine use}

Measured by self-report and urinalysis, four studies reported on post-release cocaine use, with three studies, ${ }^{6,61,67}$ reporting significant reduction $(\mathrm{p}<.05)$ for participants who were receiving in-prison OST. On the other hand, Kinlock et al., ${ }^{66}$ study found no significant differences between treated and control group. Follow up period was between one and twelve months.

\section{Injecting drug use}

At one month follow up upon release, Wilson et al.'s (2012) experimental study found significant differences $(\mathrm{p}=.001)$ in frequency of injecting drug use among in-prison OST-receiving prisoners and control group. Similarly, significant difference $(\mathrm{p}=.018)$ was also found in experimental study by Rich et al. (2015) at one month follow up.

\section{Drug paraphernalia sharing}

One experimental study, ${ }^{69}$ investigated drug paraphernalia sharing upon release from prison and found significant difference $(p=.023)$ in frequency of drug paraphernalia sharing among in-prison OSTreceiving prisoners and control group. Follow up period was one month.

\section{HCV seroconversion}

Dolan et al.'s (2005) observational study explored the impact of duration of in-prison based OST on HCV seroconversion and found that period of less than five months (as opposed to longer OST treatment) was significantly $(\mathrm{p}=.01)$ associated with increased risk of HCV seroconversion (hazard ration 4,2).

\section{Treatment entry and retention}

Treatment entry upon release from prison was reported in three experimental studies with follow up periods between ten days and three months. ${ }^{56,57,66}$ Gordon et al., ${ }^{56}(p=.012)$ and Kinlock et al. ${ }^{66,67}$ $(\mathrm{p}<.05)$ studies found significant differences between in-prison OSTreceiving prisoners and control group. Magura et al., ${ }^{57}$ study found that significantly more participants on in-prison buprenorphine treatment entered community treatment, comparing to participants who were treatment with methadone ( $93 \%$ vs. $44 \%, \mathrm{p}<.001)$.

Three experimental studies, ${ }^{6,67,68}$ compared treatment retention between in-prison OST-receiving prisoners and control group. All three found that OST-receiving participants were significantly more likely to stay in treatment upon release (Gordon et al., ${ }^{6} \mathrm{p}<.001$, Kinlock et al., ${ }^{66} \mathrm{p}<.01$, Rich et al. $\left.{ }^{68} \mathrm{p}<.001\right)$. Follow up periods were between one and twelve months.

\section{Criminal activity}

Two experimental, ${ }^{6,67}$ and one observational, ${ }^{61}$ study reported on criminal activities upon release from prison and produced mixed results. Gordon et al., ${ }^{6}(p=.03)$ and Garcia et al., ${ }^{61}(p<.05)$ found significant difference between in-prison OST-receiving prisoners and control group. In contrast, Kinlock et al., ${ }^{67}$ found no significant difference $(\mathrm{p}>.05)$ between the groups.

\section{Arrests}

Two experimental studies, ${ }^{57,67}$ compared arrests between in-prison OST-receiving prisoners and control group at follow up periods of three and twelve months, and found no significant differences ( $p>.05)$.

\section{Re-incarceration}

One experimental, ${ }^{6}$ and four observational, ${ }^{60,63-65}$ studies investigated rates of re-incarceration upon release from prison at follow up periods between three months and four years, comparing in-prison OST-receiving participants and control group. Only Dolan et al. found significant difference between the groups $(\mathrm{p}<.001)$. 
Experimental study by Magura et al., ${ }^{57}$ compared re-incarceration rates between methadone and buprenorphine-treated prisoners and found no significant difference.

\section{Mortality}

Two experimental, ${ }^{66,68}$ and five observational, ${ }^{58-60,62,64}$ studies reported on mortality. Bird et al. reported significant difference $(\mathrm{p}<.001)$ in post-release mortality ( $20 \%$ reduction) between in-prison OST-receiving participants and participants who were not receiving OST, however this was only at 12 week follow up, whereas at 2 week follow up there were no significant differences. Significant difference that suggested in-prison OST as a protective factor was also reported by Gisev et al., ${ }^{62}(\mathrm{p}<.001)$, Dolan et al., ${ }^{60}(\mathrm{p}<.05)$ and Degenhardt et al., ${ }^{59}(\mathrm{p}<.05)$, however effect decayed quickly over time. In contrast, Kinlock et al., ${ }^{67}$ and Rich et al., ${ }^{68}$ found no significant differences. Whilst Marzo et al. ${ }^{64}$ reported the rate of all-cause death being eight per 1000 person-years, there is no information in terms of how many of them received in-prison OST.

\section{Synthesis}

Table 2 summarises studies and gives information about the type of the study and whether significant effect of in-prison OST was found. For in-prison outcomes, there is strong evidence that inprison OST reduces heroin use and drug paraphernalia sharing. The evidence for reduction of injecting drug use and $\mathrm{HIV} / \mathrm{HCV}$ incidence and seroconversion is inconsistent. No evidence was found that inprison OST increases the likelihood of prison treatment completion, in comparison with in-prison drug treatment offering counselling only without OST.

For post-release outcomes, there is consistent evidence that inprison OST reduces heroin use, injecting drug use, drug paraphernalia sharing, $\mathrm{HCV}$ seroconversion, treatment entry and retention. Evidence for reduction in cocaine use, criminal activity and mortality is inconsistent. There is weak evidence for in-prison OST's association with reduction of re-incarceration, and no evidence for association with reduction of arrests upon release from prison.

Table 2 Summary of studies per outcome

\begin{tabular}{|c|c|c|c|}
\hline Outcome & Study Type & Positive Outcome at $\mathrm{p}<.05$ & No Significant Effect \\
\hline \multicolumn{4}{|l|}{ In prison } \\
\hline \multirow[t]{2}{*}{ Heroin use } & $\mathrm{RCT}$ & Dolan et al..$^{55}$ & \\
\hline & OBS & Heimer et al..$^{52}$ & \\
\hline \multirow[t]{2}{*}{ Injecting drug use } & $\mathrm{RCT}$ & Dolan et al. .55 & \\
\hline & OBS & & Kinner et al. ${ }^{53}$ \\
\hline Drug paraphernalia sharing & RCT & Dolan et al. .55 & \\
\hline \multirow[t]{2}{*}{$\mathrm{HIV/HCV}$ incidence / seroconversion } & $\mathrm{RCT}$ & & Dolan et al..$^{55}$ \\
\hline & OBS & Teutsch et al. ${ }^{54}$ & \\
\hline \multicolumn{4}{|l|}{ Treatment completion } \\
\hline & $\mathrm{RCT}$ & & Magura et al..$^{57}$ \\
\hline & RCT & & Gordon et al. ${ }^{56}$ \\
\hline \multicolumn{4}{|l|}{ Post-release } \\
\hline \multirow[t]{6}{*}{ Heroin use } & OBS & Garcia et al. ${ }^{61}$ & \\
\hline & $\mathrm{RCT}$ & Gordon et al. ${ }^{6}$ & \\
\hline & $\mathrm{RCT}$ & Kinlock et al. ${ }^{66}$ & \\
\hline & $\mathrm{RCT}$ & Kinlock et al. ${ }^{67}$ & \\
\hline & $\mathrm{RCT}$ & Magura et al..$^{57}$ & \\
\hline & $\mathrm{RCT}$ & Rich et al. ${ }^{68}$ & \\
\hline \multirow[t]{4}{*}{ Cocaine use } & OBS & Garcia et al..$^{61}$ & \\
\hline & $\mathrm{RCT}$ & Gordon et al. ${ }^{6}$ & \\
\hline & $\mathrm{RCT}$ & & Kinlock et al..$^{66}$ \\
\hline & $\mathrm{RCT}$ & Kinlock et al. ${ }^{67}$ & \\
\hline \multirow[t]{2}{*}{ Injecting drug use } & RCT & Rich et al. ${ }^{68}$ & \\
\hline & $\mathrm{RCT}$ & Wilson et al. ${ }^{69}$ & \\
\hline Drug paraphernalia sharing & RCT & Wilson et al. ${ }^{69}$ & \\
\hline
\end{tabular}




\begin{tabular}{|c|c|c|c|}
\hline Outcome & Study Type & Positive Outcome at $\mathrm{p}<.05$ & No Significant Effect \\
\hline HCV seroconversion & OBS & Dolan et al. ${ }^{60}$ & \\
\hline \multirow[t]{3}{*}{ Treatment entry } & RCT & Gordon et al. ${ }^{56}$ & \\
\hline & RCT & Kinlock et al. ${ }^{66}$ & \\
\hline & RCT & Magura et al. ${ }^{57}$ & \\
\hline \multirow[t]{3}{*}{ Treatment retention } & RCT & Gordon et al. ${ }^{6}$ & \\
\hline & RCT & Kinlock et al. ${ }^{67}$ & \\
\hline & RCT & Rich et al. ${ }^{68}$ & \\
\hline \multirow[t]{3}{*}{ Criminal activity } & OBS & Garcia et al..$^{61}$ & \\
\hline & RCT & Gordon et al. ${ }^{6}$ & \\
\hline & $\mathrm{RCT}$ & & Kinlock et al. ${ }^{67}$ \\
\hline \multirow[t]{2}{*}{ Arrests } & RCT & & Kinlock et al. ${ }^{67}$ \\
\hline & RCT & & Magura et al..$^{57}$ \\
\hline \multirow[t]{6}{*}{ Re-incarceration } & RCT & & Gordon et al. ${ }^{6}$ \\
\hline & OBS & Dolan et al. ${ }^{60}$ & \\
\hline & OBS & & Larney et al. ${ }^{63}$ \\
\hline & OBS & & Marzo et al. ${ }^{64}$ \\
\hline & OBS & & McMillan et al. ${ }^{65}$ \\
\hline & $\mathrm{RCT}$ & & Magura et al. ${ }^{57}$ \\
\hline \multirow[t]{6}{*}{ Mortality } & OBS & Bird et al. ${ }^{58}$ & \\
\hline & OBS & Degenhardt et al. ${ }^{59}$ & \\
\hline & OBS & Dolan et al. ${ }^{60}$ & \\
\hline & OBS & Gisev et al. ${ }^{62}$ & \\
\hline & $\mathrm{RCT}$ & & Kinlock et al. ${ }^{66}$ \\
\hline & $\mathrm{RCT}$ & & Rich et al. ${ }^{68}$ \\
\hline
\end{tabular}

\section{Discussion}

Prison-based OST was found to be significantly correlated with reduction of heroin use and drug paraphernalia sharing during incarceration, ${ }^{52,55}$ which is consistent with previous findings. ${ }^{70,71}$ Additionally, several qualitative studies that focused on prisoners' experience of drug use and prison-based OST also reported reduction of illicit drug use and drug related risk behaviour. ${ }^{72,73}$ Surprisingly, support for effectiveness of prison-based OST for reduction of injecting drug use in prison was mixed: whilst Dolan et al., ${ }^{55}$ study confirmed it, Kinner et al., ${ }^{53}$ found no significant effect. This is somewhat contradictory with previous studies which produced strong evidence of its beneficial impact on in-prison intravenous drug use. ${ }^{70,71,74}$ Studies included in this review produced consistent support for effectiveness of prison-based OST for reduction of post-release injecting drug use. ${ }^{68,69}$ Whilst this is in accordance with previous research, ${ }^{70}$ it must be emphasised that neither of the two studies explored to what extent the effect was mediated by engagement in post-release OST.

All six studies that included data on continuation of community OST upon release reported significant effect of prison-based OST on treatment entry and retention. ${ }^{6,56,57,66-68}$ This suggests that prisonbased OST can be a valuable opportunity to engage in treatment one of the most hard-to-reach populations who often do not seek treatment on their own. With focus on continuity of treatment upon release, treatment retention and recovery can be greatly increased. This has important implications for practice.

Evidence from this review suggests that prison-based OST has strong effect on post-release reduction of heroin, ${ }^{6,57,61,66-68}$ and crack use, ${ }^{6,61,67}$ although support was stronger for heroin use, with one study, ${ }^{66}$ reporting no significant effect on reduction of crack use. This is not surprising, as OST is treatment for opioid dependence which does not directly target crack use. One potential explanation of its association with reduction of crack use could be that OST, accompanied with harm minimisation and relapse prevention advice, impacts crack use in combination with the psychosocial intervention, although it has no pharmacological effect on stimulant use.

Review produces strong evidence of effectiveness of prisonbased OST in reduction of drug paraphernalia sharing,,$^{55,69}$ and inconsistent evidence for its impact on $\mathrm{HIV} / \mathrm{HCV}$ incidence. Whilst the two studies, ${ }^{54,55}$ which included data on in-prison $\mathrm{HIV} / \mathrm{HCV}$ 
seroconversion generated contradictory results, previous research has produced strong supportive evidence of effectiveness of OST in reduction of $\mathrm{HIV} / \mathrm{HCV}$ seroconversion, both in community, ${ }^{75,76-78}$ and prison setting. ${ }^{45}$ This review produced some evidence on impact of prison-based OST on reduction of criminal activity, ${ }^{6,61}$ however no significant effect was found on post-prison arrests, and only one study ${ }^{60}$ reported its positive effect on reduction of re-incarceration. In studies that reported on post-release recidivism, variables such as previous criminal activity, arrests, convictions, sentences and incarcerations, acted as stronger predictors of recidivism than inprison OST.

Four of six studies ${ }^{58-60,62}$ found prison-based OST associated with significant reduction of post-release mortality, however the effect tended to decay with time. Studies did not differentiate between drug related deaths and deaths from other causes, so it was not possible to assess the impact of prison-based OST on post-release overdose deaths. Due to increased risk of drug overdose death upon release from prison, ${ }^{19}$ further research would be needed to investigate the potential of prison-based OST as a protective factor from fatal overdoses.

\section{Limitations}

Studies included in this review had several limitations. Only eight studies were randomised controlled trials which allowed to explore causality and not solely correlation between variables. However, randomised controlled trials that would withhold OST are becoming progressively harder to conduct from an ethical point of view. As research in the past decades has produced strong supportive evidence for effectiveness of prison-based OST, it has become ethically problematic to withhold it from people who are clinically diagnosed with opioid dependence. ${ }^{11}$

Studies carried risk of different bias, such as social acceptability bias in self-report and baseline differences between treatment and control group in the studies. Selection bias could have an impact in terms of magnifying or minimising treatment effects. ${ }^{11}$ For example, Heimer et al., ${ }^{52}$ study reported substantially higher baseline levels of heroin use among OST-receiving prisoners than control group $(100 \%$ versus $57.5 \%, p<.005)$. This could lessen the treatment effect on heroin use outcomes. Additionally, several studies, ${ }^{52,61}$ had small samples which could result in understating the treatment effect. Other methodological limitations include retrospective reporting, ${ }^{62}$ and lack of generalisability. ${ }^{55}$ Furthermore, it was often unclear to what extent prison-based OST impacted post-release outcomes and how much of its effect was mediated by other variables, such as post-release community-based OST. ${ }^{11}$

None of the studies focused on comparison of effectiveness of prison-based OST at different doses of medication. Further research exploring impact of different doses of prison-based OST on in-prison and post-release outcomes would therefore be beneficial. Only one study ${ }^{61}$ focused on in-prison buprenorphine-naloxone treatment and whilst it produced supporting evidence for its benefits, these results could not be generalised. Further studies that would investigate prison-based buprenorphine-naloxone treatment would need to be conducted. These could focus on comparison with non-OST treated control group or with OST-treated group who would receive methadone or buprenorphine treatment.

As there was great methodological variability in the studies which reported on different outcomes, this resulted in some outcomes, such as heroin use, mortality and re-incarceration, being investigated in many studies, whilst some of the others were reported only in few. For example, only a small amount of studies explored impact of in-prison OST on drug paraphernalia sharing, ${ }^{55,69}$ and HIV/HCV seroconversion. ${ }^{54,55,60}$ Regrettably, whilst several studies reported on mortality rate, none of them differentiated between drug related deaths and deaths from other causes. As recent release from prison increases the risk of drug overdose death multiple times, ${ }^{17,19}$ further research would be necessary to thoroughly investigate the role of inprison OST and its potential to serve as a protective factor from postrelease accidental opioid overdose.

\section{Conclusion}

This review produced strong evidence of multiple benefits of prisonbased OST in terms of improvement of treatment uptake and retention and reduction of heroin use, injecting behaviour, drug paraphernalia sharing and mortality. Some of the studies demonstrated that it is beneficial for reduction in crack use, $\mathrm{HIV} / \mathrm{HCV}$ seroconversion and criminal activity. Prison-based OST is a unique opportunity to engage in drug treatment one of the most high-risk and hard-to-reach groups. As such, it can contribute to significant improvement of individuals' health and social functioning, as well as of safety and welfare of the communities. Although the availability of prison-based OST varies between different countries and regions, there is a consistent trend of its wider implementation in the past two decades. Whilst existing research provided strong evidence for effectiveness of prison-based OST, further studies are needed to explore its long-term outcomes. Future research should also investigate the impact of different doses of prison-based OST on in-prison and post-release outcomes. Additionally, further studies are needed to explore effectiveness of in-prison buprenorphine-naloxone treatment in comparison with nonOST treated control group, OST-treated group who receive methadone and OST-treated group who receive buprenorphine. Succeeding studies about impact of prison-based OST on post-release outcomes should also clarify the mediating role of other variables. Furthermore, future research would benefit from investigating the potential of inprison OST to act as a preventive factor from post-release accidental overdose.

\section{Acknowledgements}

None.

\section{Conflict of interest}

Lana Durjava declares no conflict of interest.

\section{References}

1. European Monitoring Centre for Drugs and Drug Addiction. Prisons and drugs in Europe: The problem and responses. Europe, Luxembourg: Publications Office of the European Union; 2012:1-36.

2. Bullock T. Changing levels of drug use before, during and after imprisonment. In: Ramsay M, editor. Prisoners' drug use and treatment: seven research studies. UK, London: Home Office Research, Development and Statistics Directorate; 2003:23-48.

3. Strang J, Gossop M, Heuston J, et al. Persistence of drug use during imprisonment: relationship of drug type, recency of use and severity of dependence to use of heroin, cocaine and amphetamine in prison. Addiction. 2006;101(8):1125-1132.

4. Boys A, Farrell M, Bebbington P, et al. Drug use and initiation in prison: results from a national prison survey in England and Wales. Addiction. 2002;97(12):1551-1560. 
5. Durjava L, Visick A, Banbury S. Heroin addiction in British prisons: an interpretative phenomenological analysis. MOJ Addict Med Ther. 2018;5(2):62-67.

6. Gordon MS, Kinlock TW, Schwartz RP, et al. A randomized clinical trial of methadone maintenance for prisoners: findings at 6 months postrelease. Addiction. 2008;103(8):1333-1342.

7. Keller TE, Catalano RF, Haggerty KP, et al. Parent figure transitions and delinquency and drug use among early adolescent children of substance abusers. Am J Drug Alcohol Abuse. 2002;28(3):399-427.

8. Mark TL, Woody GE, Juday T, et al. The economic costs of heroin addiction in the United States. Drug Alcohol Depend. 2001;61(2):195-206.

9. Champion JK, Taylor A, Hutchinson S, et al. Incidence of hepatitis $\mathrm{C}$ virus infection and associated risk factors among Scottish prison inmates: a cohort study. Am J Epidemiol. 2004;159(5):514-519.

10. Darke S, Kaye S, Finlay-Jones R. Drug use and injection risktaking among prison methadone maintenance patients. Addiction. 1998;93(8):1169-1175.

11. Hedrich D, Alves P, Farrell M, et al. The effectiveness of opioid maintenance treatment in prison settings: a systematic review. Addiction. 2012;107(3):501-517.

12. Taylor A, Goldberg D, Emslie J, et al. Outbreak of HIV infection in a Scottish prison. BMJ. 1995;310(6975):289-292.

13. Dolan KA, Wodak A. HIV transmission in a prison system in an Australian State. Med J Aust. 1999;171(1):14-17.

14. Hagan H, Snyder N, Hough E, et al. Case-reporting of acute hepatitis B and C among injection drug users. J Urban Health. 2002;79(4):579-585.

15. Jürgens R, Ball A, Verster A. Interventions to reduce HIV transmission related to injecting drug use in prison. The Lancet infectious diseases. 2009;9(1):57-66.

16. Inciardi JA, McBride D, Surratt H. The heroin street addict: Profiling a national population. In: Inciardi JA, Harrison L, editors. Heroin in the age of crack-cocaine. USA, Thousand Oaks, Sage; 1998:31-50.

17. Binswanger IA1, Stern MF, Deyo RA, et al. Release from prison-a high risk of death for former inmates. $N$ Engl J Med. 2007;356(2):157-165.

18. Degenhardt L, Bucello C, Mathers B, et al. Mortality among regular or dependent users of heroin and other opioids: a systematic review and meta-analysis of cohort studies. Addiction. 2011;106(1):32-51.

19. Farrell M, Marsden J. Acute risk of drug-related death among newly released prisoners in England and Wales. Addiction. 2007;103(2):251-255.

20. Kinlock TW, O'Grady KE, Hanlon TE. Prediction of the crimina activity of incarcerated drug-abusing offenders. Journal of Drug Issues. 2003;33(4):897-920.

21. Kinlock TW, Gordon MS, Schwartz RP, et al. A Study of Methadone Maintenance for Male Prisoners 3-Month Postrelease Outcomes. Crim Justice Behav. 2008;35(1):34-47.

22. Hanlon TE, Nurco DN, Bateman RW, et al. The response of drug abuser parolees to a combination of treatment and intensive supervision. The Prison Journal. 1998;78(1):31-44.

23. Johnson RE, Chutuape MA, Strain EC, et al. A comparison of levomethadyl acetate, buprenorphine, and methadone for opioid dependence. N Engl J Med. 2000;343(18):1290-1297.

24. Mattick RP, Breen C, Kimber J, et al. Methadone maintenance therapy versus no opioid replacement therapy for opioid dependence. Cochrane Database Syst Rev. 2009;3(3):CD002209.

25. Schwartz RP, Highfield DA, Jaffe JH, et al. A randomized controlled trial of interim methadone maintenance. Arch Gen Psychiatry. 2006;63(1):102-109

26. Howells C, Allen S, Gupta J, et al. Prison based detoxification for opioid dependence: a randomised double blind controlled trial of lofexidine and methadone. Drug Alcohol Depend. 2002;67(2):169-176.

27. Kerr T, Jürgens R. Methadone maintenance therapy in prisons: reviewing the evidence. Canada, Montreal, Canadian HIV/AIDS Legal Network; 2004:1-7.

28. Stöver H, Casselman J, Hennebel L. Substitution treatment in European prisons: A study of policies and practices in 18 European countries. International Journal of Prisoner Health. 2006;2(1):3-12.

29. Bass UF, Brown BS. Methadone maintenance and methadone detoxification: A comparison of retention rates and client characteristics. International journal of the Addictions. 1973;8(6):889-895.

30. Masson CL, Barnett PG, Sees KL, et al. Cost and cost-effectiveness of standard methadone maintenance treatment compared to enriched 180day methadone detoxification. Addiction. 2004;99(6):718-726.

31. Caplehorn JR, Dalton MS, Cluff MC, et al. Retention in methadone maintenance and heroin addicts' risk of death. Addiction. 1994;89(2):203-209.

32. Gottheil E, Sterling RC, Weinstein SP. Diminished illicit drug use as a consequence of long-term methadone maintenance. $J$ Addict Dis. 1993;12(4):45-57.

33. Newman RG, Bashkow S, Cates M. Arrest histories before and after admission to a methadone maintenance treatment program. Contemp Drug Probs. 1973;2:417.

34. Keen J, Rowse G, Mathers N, et al. Can methadone maintenance for heroin-dependent patients retained in general practice reduce criminal conviction rates and time spent in prison? Br J Gen Pract. 2000;50(450):48-49.

35. Wickersham JA, Zahari MM, Azar MM, et al. Methadone dose at the time of release from prison significantly influences retention in treatment: implications from a pilot study of HIV-infected prisoners transitioning to the community in Malaysia. Drug Alcohol Depend. 2013;132(1-2):378-382.

36. World Health Organization (WHO). Interventions to Address HIV in Prison: Drug Dependence Treatment. Switzerland, Geneva: World Health Organization; 2007:1-36.

37. Møller L, Gatherer A, Jürgens R, et al. Health in prisons: a WHO guide to the essentials in prison health. Switzerland, Geneva: World Health Organization Regional Office Europe; 2007:198 p.

38. WHO/UNODC/UNAIDS position paper: Substitution maintenance therapy in the management of opioid dependence and HIV/AIDS prevention. Switzerland, Geneva: World Health Organization; 2004:1-36.

39. Hedrich D, Farrell M. Opioid maintenance in European prisons: is the treatment gap closing? Addiction. 2012;107(3):461-463.

40. Zurhold H, Stöver H. Provision of harm reduction and drug treatment services in custodial settings-Findings from the European ACCESS study. Drugs: Education, Prevention and Policy. 2016;23(2):127-134.

41. Stone K. The global state of harm reduction. UK, London: Harm Reduction International; 2016:148 p.

42. Stöver H, Nelles J. Ten years of experience with needle and syringe exchange programmes in European prisons. International Journal of Drug Policy. 2003;14(5-6):437-444.

43. Stefan Enggist, Lars Møller, Gauden Galea, et al. Prisons and Health WHO Guide. Austria, Vienna; 2014:207 p. 
44. Fazel S, Bains P, Doll H. Substance abuse and dependence in prisoners: a systematic review. Addiction. 2006;101(2):181-191.

45. Spaulding A, Stephenson B, Macalino G, et al. Human immunodeficiency virus in correctional facilities: a review. Clin Infect Dis. 2002;35(3):305-312.

46. Werb D, Kerr T, Small W, et al. HIV risks associated with incarceration among injection drug users: implications for prison-based public health strategies. J Public Health (Oxf). 2008;30(2):126-132.

47. Zamani S, Farnia M, Torknejad A, et al. Patterns of drug use and HIVrelated risk behaviors among incarcerated people in a prison in Iran. $J$ Urban Health. 2010;87(4):603-616.

48. Merrall EL, Kariminia A, Binswanger IA, et al. Meta-analysis of drug-related deaths soon after release from prison. Addiction. 2010;105(9):1545-1554.

49. World Health Organization (WHO). Prevention of Acute Drug-Related Mortality in Prison Populations during the Immediate Post-Release Period. Denmark, Copenhagen: World Health Organization Regional Office; 2010:1-33.

50. Cropsey KL, Villalobos GC, St Clair CL. Pharmacotherapy treatment in substance-dependent correctional populations: a review. Subst Use Misuse. 2005;40(13-14):1983-1999.

51. Stallwitz A, Stöver H. The impact of substitution treatment in prisons--a literature review. Int J Drug Policy. 2007;18(6):464-474.

52. Heimer R, Catania H, Newman RG, et al. Methadone maintenance in prison: evaluation of a pilot program in Puerto Rico. Drug Alcohol Depend. 2006;83(2):122-129.

53. Kinner SA, Moore E, Spittal MJ, et al. Opiate substitution treatment to reduce in-prison drug injection: a natural experiment. Int J Drug Policy. 2013;24(5):460-463.

54. Teutsch S, Luciani F, Scheuer N, et al. Incidence of primary hepatitis $\mathrm{C}$ infection and risk factors for transmission in an Australian prisoner cohort. BMC Public Health. 2010;10:633.

55. Dolan KA, Shearer J, MacDonald M, et al. A randomised controlled trial of methadone maintenance treatment versus wait list control in an Australian prison system. Drug Alcohol Depend. 2003;72(1):59-65.

56. Gordon MS, Kinlock TW, Schwartz RP, et al. A randomized controlled trial of prison-initiated buprenorphine: prison outcomes and community treatment entry. Drug Alcohol Depend. 2014;142:33-40.

57. Magura S, Lee JD, Hershberger J, et al. Buprenorphine and methadone maintenance in jail and post-release: a randomized clinical trial. Drug Alcohol Depend. 2009;99(1-3): 222-230.

58. Bird SM, Fischbacher CM, Graham L, et al. Impact of opioid substitution therapy for Scotland's prisoners on drug-related deaths soon after prisoner release. Addiction. 2015;110(10):1617-1624.

59. Degenhardt L, Larney S, Kimber J, et al. The impact of opioid substitution therapy on mortality post-release from prison: retrospective data linkage study. Addiction. 2014;109(8):1306-1317.

60. Dolan KA, Shearer J, White B, et al. Four-year follow-up of imprisoned male heroin users and methadone treatment: mortality, re-incarceration and hepatitis C infection. Addiction. 2005;100(6):820-828.

61. Garcia CA, Correa GC, Viver AD, et al. Buprenorphine-naloxone treatment for pre-release opioid-dependent inmates in Puerto Rico. $J$ Addict Med. 2007;1(3):126-132.
62. Gisev N, Shanahan M, Weatherburn DJ, et al. A Cost-Effectiveness Analysis of Opioid Substitution Therapy upon Release in Reducing Mortality among Prisoners with a History of Opioid Dependence. Addiction. 2015;110(12):1975-1984.

63. Larney S, Toson B, Burns L, et al. Effect of prison-based opioid substitution treatment and post-release retention in treatment on risk of re-incarceration. Addiction. 2012;107(2):372-380.

64. Marzo JN, Rotily M, Meroueh F, et al. Maintenance therapy and 3-year outcome of opioid-dependent prisoners: a prospective study in France (2003-06). Addiction. 2009;104(7):1233-1240.

65. McMillan GP, Lapham S, Lackey M. The effect of a jail methadone maintenance therapy (MMT) program on inmate recidivism. Addiction. 2008;103(12):2017-2023.

66. Kinlock TW, Gordon MS, Schwartz RP, et al. A randomized clinical trial of methadone maintenance for prisoners: results at 1-month post-release. Drug Alcohol Depend. 2007;91(2-3):220-227.

67. Kinlock TW, Gordon MS, Schwartz R, et al. A Randomized Clinica Trial of Methadone Maintenance for Prisoners: Results at TwelveMonths Post-Release. J Subst Abuse Treat. 2009;37(3):277-285.

68. Rich JD, McKenzie M, Larney S, et al. Methadone continuation versus forced withdrawal on incarceration in a combined US prison and jail: a randomised, open-label trial. The Lancet. 2015;386(9991):350-359.

69. Wilson ME, Kinlock TW, Gordon MS, et al. Postprison release HIV-risk behaviors in a randomized trial of methadone treatment for prisoners. Am J Addict. 2012;21(5):476-487.

70. Dolan K, Hall W, Wodak A. Methadone maintenance reduces injecting in prison. BMJ. 1996;312(7039):1162.

71. Dolan KA, Wodak AD, Hall WD. Methadone maintenance treatment reduces heroin injection in New South Wales prisons. Drug Alcohol Rev. 1998;17(2):153-158

72. Awgu E, Magura S, Rosenblum A. Heroin-dependent inmates' experiences with buprenorphine or methadone maintenance. $J$ Psychoactive Drugs. 2010;42(3):339-346.

73. Long J, Allwright S, Begley C. Prisoners'views of injecting drug use and harm reduction in Irish prisons. International Journal of Drug Policy. 2004;15(2):139-149.

74. Zamani S. Pattern of drug-related risk behaviours after the introduction of methadone maintenance treatment or a needle/syringe exchange program among drug-using prisoners in two prisons in Iran. Kyoto: Kyoto University School of Public Health; 2010.

75. Gowing L, Farrell M, Bornemann R, et al. Substitution treatment of injecting opioid users for prevention of HIV infection. Cochrane Database Syst Rev. 2004;(4):CD004145.

76. Metzger DS, Navaline H, Woody GE. Drug abuse treatment as AIDS prevention. Public Health Rep. 1998;113(Suppl 1):97-106.

77. Ward J, Hall W, Mattick RP. Role of maintenance treatment in opioid dependence. The Lancet. 1999;353(9148):221-226.

78. World Health Organization (WHO). Guidelines for the psychosocially assisted pharmacological treatment of opioid dependence. Switzerland, Geneva: World Health Organization; 2009:134 p. 